\title{
Elements of biography in the works of V. Stefanyk and E. Caldwell
}

\section{O. Hnatiuk}

\author{
Vasyl Stefanyk Precarpathian National University, Ivano-Frankivsk, Ukraine \\ Corresponding author. E-mail: ginger84@ukr.net
}

Paper received 02.11.19; Accepted for publication 15.11.19.

\section{https://doi.org/10.31174/SEND-Ph2019-211VII62-05}

Abstract. The article analyzes and compares biographical elements in literary works of V. Stefanyk and E. Caldwell. The attention is paid to studying short stories and peculiarities of biographical method, which reveals the connection between the authors' personalities and their writing.

Keywords: Biographical, peculiarity, method, impressions, grief, village.

Introduction. When studying the peculiarities of the creative activity of writers, it is natural to refer to the biographical method, since it testifies to the connection between the writer's personality and his work.

According to the definition of literary dictionary, biographysm (Greek bios - life and graphic writing, I represent) a number of literary concepts related to the way of life of the writer and his work. It covers the actual biography, autobiography (the author's biography), bibliography (a combination of a biography with a bibliography of works by the artist). The essence of biography is that the work of the writer is closely connected with his life story, with the features of his personality. The traditions of this method proved to be rather lasting, which is natural, since it is a question of the individual uniqueness of creativity, of the author, as a peculiar, extraordinary person [6].

When a writer has deep feelings, when he is really bothered by something, he will spread everything on paper simply and without embellishment. Writing a literary work, the writer is inventing a plot or motive, but if the artist uses material taken from his own life, he uses it in the finished form. The life of V. Stefanyk and E. Caldwell was so eventful that they did not need to invent anything or borrow someone else's experience. Those events that they saw or met with was quite enough for all their literary work. Each line of their novels is full of pain, sadness and life experience.

Objective: to define biographical elements in literary works of V. Stefanyk and E. Caldwell; to conduct a comparative analysis of their writing; to find similaties and differences.

Main results and discussion. According to Y. Gamorak's opinion: "The best biography of V. Stefanyk is his works. The truth of his creativity is the truth of his life and that truth he "sharpens in the flames of his soul" ("My word"). Therefore, the best source for the knowledge of the life of V. Stefanyk is his works "[2, p.5].

V. Stefanyk, as well as E. Caldwell, experienced and recognized the black need of their native land very early. Since E. Caldwell was born in Georgia, he spent all his childhood there, in the south of America. The main occupation of the residents of this state was the cultivation of tobacco and over time, tobacco began to crowd out the cultivation of cotton. Because of this, the land was depleted and many farmers became bankrupt and became impoverished. The unhappy impressions of childhood have been engraved in the memory of the writer, and the state of Georgia has become the venue for many of his stories. Since 12, the future writer has started to work on a farm, and at night - at the butter factory; since then he knew well about a hard physical work.

The same we can observe in the biography of V. Stefanyk, who also worked hard on the field with his father in his childhood. His father, blinded by the desire for enrichment, cruelly treated hires and even members of the family. Therefore, in his child's heart the feeling of anger against the exploiters was repeatedly boiled up because of the unfair and cruel attitude towards the rural poor people and the hardship, and consequently, the main theme of his short stories was the hard life of Western Ukrainian villagers.

Recruiting brought a lot of grief to the Ukrainian people. The sons of ordinary people were separated from families and persecuted for the death for the sake of the state interests. In his short stories, "Forced out of the village" and "Put to death", V. Stefanyk showed that the service in the army is equivalent to death. After all, the first story tells about parents who accompanied their son to the army, and he compares this to his death and in the second one - the boy could not withstand humiliation and mistreatment in the army and as a result he hanged. However, the impetus for writing these novels was a tragic event in the Stefanyk family. In 1897, his cousin Luka committed a suicide in the army. This prompted the artist to reflect on the cause of such an action and the fate of recruits in general.

According to O. Gnidan's opinion: "If in the short story "Forced out of the village," V. Stefanyk allowed himself some "talkativeness" (landscape frame, transmission of psychology of heroes through actions, gestures, facial expression), then in the story "Put to death" is widely applied reception of direct penetration of the author into the inner world of the character, in his consciousness, feelings and thoughts "[1, p.87].

V. Stefanyk, studying in Krakow, saw hundreds of unfortunate people, peasants from Western Ukraine, who escaped from their native land every day to the station to escape from inevitable starvation. V. Stefanyk was very worried by the fate of the emigrants, so the theme of labor emigration occupied an important place in the work of V. Stefanyk. He devoted his famous story "The Stone Cross" to the emigrants who left their homes, native land - the only work that touches on the issue of emigration. At the heart of the story - a fact from the life of the writer. His fellow-villager poor Stefan Didukh (in a short story - Ivan), emigrating to Canada, placed a stone cross in his field. However, this is not just a story from the life of V. Stefanyk, but a great artistic synthesis of the author's reflections on labor emigration. The writer was concerned with their fate, as he knew well that they were waiting there far from home. Almost the entire story is a demonstration of the oppressive experiences of a peasant who goes to inevitable death in strange and unknown regions. It should be noted that V. Stefanyk himself worried about the peasant's mental agony, who was forced to part with his homeland. All the attention of the writer focuses on the inner experiences of Ivan Didukh. Imbued with grief, Didukh felt like a stone thrown by a wave on the shore. He himself seems to be fake, looks and sees no one. 
Since 1922, E. Caldwell has studied at the University of Virginia, with particular interest in sociology and literature. However, like V. Stefanyk, he left the university and began to engage actively in literary business: he wrote newspaper articles, reviews, chronicles. Both writers took lessons from their own lives - and this is the main source of their creativity.

E. Caldwell, as well as V. Stefanyk, sympathizes with his people and seeks to struggle with social evil as much as possible. The southern exploiters cause hatred in it. In their short stories, both writers show how poverty pushes hungry people to treason, crime, and money, giving them the right to torture and kill people with impunity. Feature stories are "On Saturday Afternoon," "In the People's Gulf," "In the East", "Candy Beecham". In these stories, we can see the senseless murder of a guest farmer, violence over a defenseless girl; here is the mother, brought to despair in order to feed hungry children, gives her 10-year-old daughter to molest.

The love for the village and for its inhabitants has become a powerful factor for artistic comprehension of national characters and types by both writers. Peasant is the protagonist of all the short stories of both artists. Poverty and hunger in Ukrainian villages generated terrible family tragedies that could not help but hurt the vulnerable creative nature of $\mathrm{V}$. Stefanyk. In the short stories like "News", "Katrusia", "Maple leaves", poorly matured parents wait when their children die, because they are not in a position to feed them "Oh, locusts, demand only bread, and bread, and bread! Where can I get you bread from? "[3, p.10].

Due to social problems and low standard of living Stefanyk's heroes may appear cruel and cynical ("and children are foam on the water... something crumbling happens to them and carry all to the grave" ("Maple leaves") [1, c.106] - opinion, expressed on christening party). However, if you look deeper, you can actually see the kindness and gentle feelings of a parent who curses his children for death, because he sees no prospect for them in the future, except for poverty and misery, no light rays. The theme of the neglected childhood, the hired fate, and the complete dependence on the master, also inspired V. Stefanyk.

E. Caldwell was the involuntary witness of several lynching that impressed him greatly and, therefore, we can see violent actions in his stories. The writer saw how one man killed his mule just on the road, because there was heat, he was tired and he could not take it anymore. In addition, working in a shed, where they kept cotton, E. Caldwell witnessed how the boss asked the Negro-slave, why his mule was walking with a limp. The negro-slave explained that the mule kicked the rabbit trap, but the boss was angry and beat the Negro to halfdead, knowing well that he was innocent, but would not defend himself.

Thus in the novels of E. Caldwell the motive of social protest is strengthened not only against oppression of the poor people, not only against the very fact of lynching and grumbling over the negro, but also against the social conditions that give rise to and make possible these crimes.

That is, the condolences of the little man in stories of E. Caldwell and V. Stefanyk grow into a conscious respect for the strong people capable of struggle.

According to O. Hnidan: "Chronic poverty of people dark, slaughtered, and humiliated - is an extremely significant sign of peasant life at the turn of the century. V. Stefanyk sympathizes with the desperate heroes and loves them. However, the writer's love is hidden, between the lines, but it is sincere and true, without idealization and sentimental hearts and flowers"[1, p.110].

In the unfinished story "Rich man", written during the most severe conflict with his father, V. Stefanyk tells how his father got rich. The main source of enrichment was the cattle that his father Semen grew and sent to the Viennese markets for sale, because meat there cost much more than in Bukovyna or Galicia. He was fierce in labor. He did not give rest to either his wife or his children. The prototype of Stefanyk's father Ivan from the story "Rich man" shows cruelty not only in relation to cattle, but also to people "[8].

In the story "The boy from Georgia," E. Caldwell remembers his legendary grandfather, who is similar to the hero of the story Morris Stroup. The latter is a safe dreamer and idle worker - the father of the family. As E. Caldwell himself described his grandfather: "... for all his life he did not work for one day, but was considered a very intelligent man and was an incomparable master of fairy tales and all sorts of stories" [10].

With unique poeticism, V. Stefanyk reproduced the image of his mother in the short stories "Evening Hour", "Thread", "My Word". His mother was loaded with all the work on a huge farm that finally brought her to the grave prematurely. In the story of "Basaraby" Stefanyk's mother presides over the whole family: "She stood at the table high, grey-haired and simple. Her eyes were large, grey, and smart. She looked with them as if there was no such a corner in the whole world that she would not know about" [2, p.17].

According to Yu. Hamorak's opinion: "V. Stefanyk's mother Oksana, like every Ukrainian woman, is a guard of the home hearth and old peasant traditions she is a woman with a big heart. His sister Maria is a friend of his childhood and at the same time his best guardian. The mother and sister gave him so much warmth and love during his childhood that the living memory of them willforeverremaininhis heart "[2,p.7].

In the story of E. Caldwell, "A boy from Georgia," the mother also appears as a strong woman, who keeps the whole house. However, the relationship of the parents was tense, because mom was always not in humor due to lack of money. In addition, the mother hard earned a penny, performing the difficult work of the lumber. Although this story the writer portrayed in a comic manner, however, in all anecdotal situations, a great life drama is hidden.

In addition, the story of V. Stefanyk "Basaraby" is (metaphorized) a kind of history of the Stefanyk family. In one of his letters, the writer wrote, "There are many suicide cases in the Stefanyk family. My essay "Basaraby" - that is, the true story of the family name "[4, p.19].

V. Kostaschuk, a friend of V. Stefanyk and one of his first biographers, in his book "The Lord of Peasants' Thoughts," wrote that the great-grandfather of V. Stefanyk, Theodore, had built a house in Rusove village. As he was not a local man, people of Rusove called him "basarab" [9]. About V.Stefanyk's grandfather, Luka, people have kept a bad memory; they considered him a cruel and evil man. Luka Stefanik committed a suicide, which caused a shame to the family. Actually, the fate of his grandfatherV.Stefanyk will take as abasisfor the creation of the already mentioned short story "Basaraby".

The death of loved ones was a fate of V. Stefanyk and it persecuted him all his life. He did not need to invent anything, because he suffered a lot of grief in real life. Therefore, it is not surprising that the death of his sister, and then his mother, caused an indescribable pain to V. Stefanyk. So the short story "Evening Hour" was written as a reaction to the death of the loved ones. The writer embodied all his pain and anguish for 
the lost dear people in this short story: "And then my mother died. Mother's coffin near Maria's one. The flowers from the mother's cherry tree fall to the tomb of Mary, and from Mary's tomb to her mother's one. I was there once. I was sitting between those coffins and remembering my mother's songs. Only a cherry blossom from the tombs was flying for me, as if it asked me by my sister and mom not to go... [2. p. 55].

No less tragic fate of Stefanyk's friend, Fyodor Kotyuk, led to the writing of the novel "The Letter". Tragedy lies in the fact that the young, active participant in the radical movement, during his quarrels and fights with his wife, accidentally killed her, for not allowing him to conduct election campaigning. He was sentenced to seven years in prison. He wrote to V. Stefanyk a letter asking him to take care of his children.

As O. Hnidan stated: "In dedicating the short story "Letter" to political prisoners of war, V. Stefanyk thus emphasized full solidarity with them - courageous and fearless, convinced of the truth of the holy cause, indestructible in the trials. The story is also addressed to people in freedom, in which the conscience must awaken "[1, p.150].

The heroine of the story "Signature" - Evdokia Stefanyk, the writer's niece. He portrayed her as a child, who will soon become a teenager, she masters the ability to learn and own acquired knowledge. Dotsia, despite her young age, becomes a "teacher" for adult men. She behaves very much as an adult, and responds responsibly to her task - to teach illiterate men the signature.

In many of Stefanyk's short stories, which we discussed, we mentioned the use of autobiographical material. However, besides them, during the first and second periods of creativity the writer created several completely autobiographical novels "Thread", "Brothers", whose main heroine was the "beloved mother" of the artist. Most often, V. Stefanyk mentioned his mother as healthy, young, and beautiful, that is, what he remembered in childhood. The main feature of the image of the mother - a great love for their children, the desire to see them healthy, intelligent, honest. She cared about her family throughout her life, and no work was hard for her. The image of the mother in these short stories is wrapped up with deep son's love and gratitude.

If we look at the works of E. Caldwell, then we will notice that the only autobiographical story is "The boy from Georgia" and there we can learn only about the childhood of the artist, although the story itself is not about childhood. Here we can see the world of adults, perceived by the eyes of the child, who had to grow up quickly, a world devoid of children's games and fantasies. Reading the funny and at the same time sad pages of the "The Boy from Georgia", we can remember the words of another great expert of American life - the brilliant artist Charlie Chaplin: "The tragedy and comedy are in fact inseparable." On the pages of this play, events that lead to mental trauma are rapidly unfolding. The farmer, having become impoverished, has reached the extreme point of alienation. Everything seems evil to him. However, the boy still sees in him a father, the only loved one. Together with him, E.
Caldwell is ready to tear up when the family of the Stroupes finally collapses. The writer, just as his heroes do not know what and how to do when "man has reached the extreme", so the pages of his work have so much bitter laugh and acute pain.

Conclusion. Therefore reading the short stories of V. Stefanyk and E. Caldwell it is hard not to notice the tragedy that covers them. Ruins, impoverished poverty, accidents, dying torture, starvation, murder, quarrels, and fights are all the contents of their short stories. For artistic reproduction, both artists chose the most tragic facts of peasant life; however, this does not mean that they were pessimists. V. Stefanyk himself said: "They say that I am a pessimist. However, this is not true. I am an optimist. I introduced your dark life and introduced your mood. Moreover, all the terrible things that are in it, and that hurts me so much, I wrote, burning, and blood with tears mingled. Nevertheless, when I found in your souls such words that they could roar like thunder and shine like stars, it was optimism "[10, p.167].

By depicting certain phenomena and characters, both writers choose from the real life only the brightest features, which in aggregate make the product even more impressive than in real life. However, both artists manage to maintain an even, calm tone of the story, reproducing even the most severe man's torment. Neither V. Stefanyk nor E. Caldwell ever give any evaluations to his heroes in the works and do not show their attitude towards them. They seem to stand aside and calmly describe what they see. The writers are interested not in external events and circumstances, but in the internal state of the characters, their experiences. That is, they saturate their stories with the profound psychology that makes their works unique and distinguishes among other masters of the word. However, at the same time, both writers never lose common sense, do not fall into excessive sensitivity, and never blacken the picture deliberately. They rarely nourish the atmosphere of their short stories, because pain, suffering, hopelessness were present in life itself, which is precisely why so much pain is in their masterpieces. Most life situations and human images were taken from life, from the lives of relatives, friends and fellow villagers.

The skill of making the plot, the richness of the language palette, the incredible depth of the word - another feature that is characteristic for both writers. They listen and reproduce in their works a living folk speech. Both artists did not have to fantasize in order to invent stories and heroes, because everything the portrayed by them - life around, real events, real people. From their very life, they drew dramatically dramatic scenes, dramatic and tragic stories that revealed the heaviness of the fate of the poor. In their writings, both writers deeply penetrate into the soul of their heroes. E. Caldwell wrote that the story should be taken directly from life. The most important thing is to live, to have a soul for what you write.

As you can see, V. Stefanyk and E. Caldwell's biographies have many similar circumstances, which undoubtedly determined the similarity of ideological convictions of both authors, systems of their aesthetic views, narrative strategies, etc.

\section{REFERENCES}
1. O. Hnidan. V. Stefanyk. Life and Writing. Kyiv "Radianska shkola", 1991, 222p.
2. V. Stefanyk "Rosa". Ivano-Frankivsk, 2015, 180p.
3. V. Lesyn Stefanyk. Novely. Uzhhorod, Karpaty publ., 1977, 175p.
4. V. Stefanyk Tvory. Kyiv, Dnipro publ., 1964.
5. V. Stefanyk Collected works in III volumes, Volume II, Kyiv, $1952,167 \mathrm{p}$.
7. V. Stefanyk Liubyv svoiu dorohy[Electronic resource ]. -Access: www.ukr-lit.net/article1/1604.html

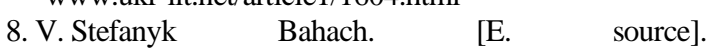
Access:http://zbruc.eu/node/37500
9. «Na vuhli» Stefanykovoi khaty[E. source]. -Access: litakcent.com/2011/04/12/na - vuhli - stefanykonoi - haty
10. V. Stefanyk[E. source]. -Access:www. rulit me/books/dlya

6. Biografizm [E. source]. - Access: ukr-lit.com/biografizm/ 